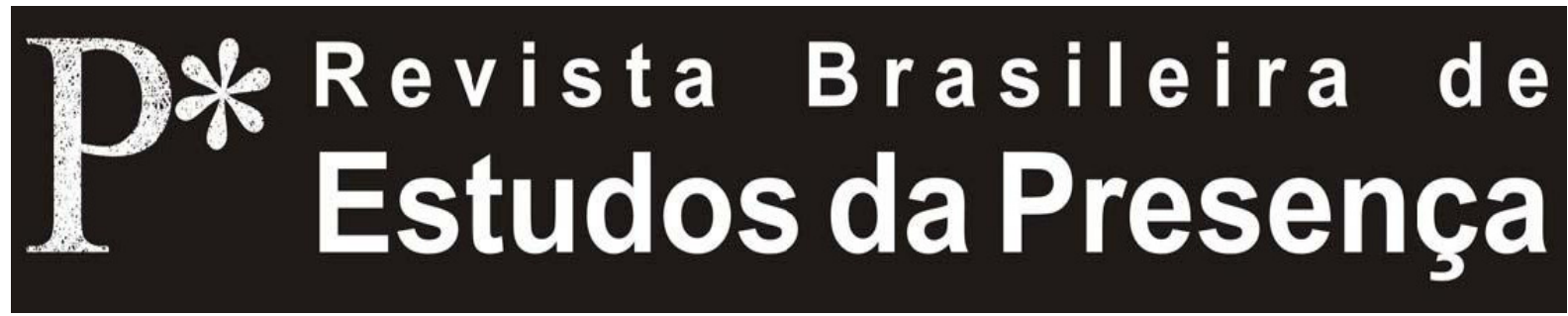

DOI - http://dx.doi.org/10.1590/2237-266024969

ISSN 2237-2660

\title{
Um Conto de Encontros com Lia Rodrigues Cia. de Danças
}

\author{
Bianca Scliar Mancini \\ Concordia University - Montreal, Canadá
}

RESUMO - Um Conto de Encontros com Lia Rodrigues Cia. de Danças - Lia Rodrigues instalou sua companhia de danças no bairro de Alagados, no Rio de Janeiro. Considera-se neste artigo sua presença nesta zona urbana como um procedimento de presença, propondo-se uma atenção à dança que antecede o processo de composição coreográfico, visto pelo publico. Para investigar como as noçóes de sítio, localização e permanência se engendram no trabalho da Companhia de danças Lia Rodrigues, a autora acompanha três dançarinos por seus percursos urbanos. Surge assim uma extensão da noçáo de coreografia e uma concepçáo da dança, que se inicia nos trajetos cotidianos dos dançarinos e do público, quando estes se permitem atravessar zonas e limites de tensão social para a execução e a fruição de uma dança.

Palavras-chave: Lia Rodrigues. Presença. Náo-dança. Site-specific. Performance.

ABSTRACT - A Tale of Encounters with Lia Rodrigues Cia. de Danças - Lia Rodrigues established her dance company in the neighbourhood of Alagados, in Rio de Janeiro. This article considers her presence at this urban zone as a procedure of presence, suggesting an attention to dance that precedes the process of choreographic composition, seen by the public. To investigate notions such as site, location and permanence and how they engender the work of her Company, the author follows three dancers through their urban trajectories. From that, a different notion of choreography arises, as well as a conception of dance that is initiated in the everyday trajectories, once one allows himself to cross the boundaries of social tension in order to execute, produce or enjoy a dance.

Keywords: Lia Rodrigues. Presence. Non-dance. Site-specific. Performance.

RÉSUMÉ - Un Conte de Rencontres avec Lia Rodrigues Cia. de Danças - Lia Rodrigues a établi sa compagnie de danse dans le quartier d'Alagados, à Rio de Janeiro. Cet article envisage sa présence dans cette zone urbaine comme un procédé de présence, proposant un regard sur cette danse qui précède le processus de composition chorégraphique montré au public. Afin de mesurer l'impact des notions de site, d'emplacement et de résidence dans le travail de Lia Rodrigues Companhia de Danças, l'auteur suit trois danseurs à travers leurs parcours urbains. Cela conduit à un élargissement de la notion de chorégraphie et à une conception de la danse qui commence dans les trajets quotidiens des danseurs et du public, lorsque ces derniers osent traverser des zones de tension sociale pour la pratique et le plaisir de la danse.

Mots-clés: Lia Rodrigues. Présence. Non-danse. Site-specific. Performance. 


\section{Lia Rodrigues: um conto de encontros}

E não é dos sonhos, da criação, em Movimento, que começamos a criar novos mundos? (Lia Rodrigues).

$O$ atual não é o que somos, mas o que nos tornamos, o que somos no processo de vir a ser - isto é, o Outro, o tornar-se Outro. O presente, inversamente, é o que somos e, portanto o que já cessamos de ser

(Deleuze; Guattari, 1994, p.119, tradução da autora).

Lia Rodrigues Companhia de Danças situa-se em uma das maiores áreas de exclusão socioeconômica urbanas no Rio de Janeiro, o Complexo da Maré. Desde sua instalação ali, em 2003, as composiçóes da Cia. de Danças têm explorado diversas estratégias que desafiam tensóes latentes nas práticas de movimento urbano, e que evidenciam as políticas e práticas espaciais cariocas. Assim, o conteúdo da ação política (Mouffe, 2005) entrelaça-se na dramaturgia da dança contemporânea composta pela coreógrafa, ainda que não seja explícito de forma denotativa nos seus espetáculos.

A chegada de Lia na Maré deu-se, inicialmente, a partir de sua participação em um projeto de ensino da dança, desenvolvido junto à ONG Redes da Maré. Iniciado como um movimento de resistência contra as demandas dos sistemas de fomento à arte vigente na época, a participação de Lia na Redes desvirtuava a exigência de uma contrapartida social, mandatória a quem pleiteasse fundos públicos para a produção e execução de uma criação artística. Frequentemente tal demanda instalava workshops, escolas livres e cursos de curta duração, que cessavam ao fim da produçáo, não oferecendo ação contínua ou autonomia técnica e criativa à comunidade. Além da problemática descontinuidade dos projetos, aponto como delicada a exigência que incidia sobre os artistas, que, para a execuçấo de um projeto pedagógico, deveriam ter uma habilidade didática, não implícita em sua prática criativa. Artistas não treinados para coordenar uma prática educativa deveriam, dentro do sistema da contrapartida social, inventar técnicas de ensino que pudessem ser integradas à produção que pretendiam executar.

Esse modelo permanece vigente, mas foi duramente criticado e vem sendo lentamente substituído nos últimos dez anos por práticas que propóem que a criação artística seja autônoma da ação de formação social que pode acarretar, assegurando que a atuação do artista como agente de transformaçáo social se dê em formatos distintos 
da docência direta de técnicas, tal como contemplada no modelo de ensino anteriormente descrito.

Além da problemática justaposição de funções sociais atribuída ao processo de criação artística, a duração dos projetos de assistência e formação não permitia a formaçáo de dançarinos, e tão pouco dava conta de processos socioeducativos que fossem efetivamente transformativos das comunidades assistidas. A rotatividade de açóes não propiciava a formação de laços mais profundos dos artistas com a comunidade e com as políticas e demandas locais. Os projetos frequentemente findavam em intervençóes rasas, cujos efeitos evaporavam tấo rápido quanto às mudanças nos modos de distribuição de fundos de fomento à cultura.

Nesse cenário, alguns artistas começaram a desenvolver pedagogias radicais, açóes sociais que tinham e pretendiam-se transformativas também de sua produção estética. Estes trabalhos, sugiro, privilegiam uma intuiçáo sobre possíveis desdobramentos da prática artística na comunidade assistida e instituem um questionamento estético que provoca o questionamento sobre o que pode o processo de criação e montagem fazer para uma determinada realidade sociocultural, mas principalmente o que pode este processo com e a partir das especificidades das comunidades atendidas.

Lia Rodrigues é um dos exemplos de atuação surgida nesse contexto. A coreógrafa iniciou na Comunidade de Alagados, um dos bairros da Maré, um movimento radical: em vez de acatar o formato desgastado de contrapartidas sociais e oferecer workshops de dança para a comunidade, propôs a transferência de sua companhia de dança para o território da Maré. Sua açáo comunitária reverteu-se assim para atender seus próprios dançarinos, privados até então das experiências do território da Maré por conta da fragmentação socioeconômica histórica do tecido urbano. Assim, a proposição de Lia pretendia que o dinamismo, o ritmo, perigos, códigos, corporealidades e imaginários específicos da Favela da Maré pudessem contaminar o vocabulário de movimento da dança contemporânea.

Quantas cidades compóem uma cidade? Pode-se arriscar dizer que são tantas quanto seu número de habitantes? Ou a cidade se compóe pela quantidade de sociedades que contém? Se, como nos sugere a filosofia processual, cada ocasião atual origina uma sociedade $^{1}$ (Whitehead, 1978, p. 34), chega-se a uma equação infinita entre experiência e a ocasião. A impossibilidade de definir o que é a 
cidade confronta-nos com a distinção entre as noções de território e a da diversidade de experiências urbanas.

O trabalho coreográfico de Lia Rodrigues busca entender a complexidade de variaçóes da experiência urbana e pressupóe a impossibilidade de definir o que é a cidade, evitando a armadilha de querer encenar uma representação fácil do que se apreende na experiência do tecido urbano. Ao compor, a partir de uma coleção de corporealidades efêmeras, a companhia condensa a importância política dos gestos e encontros cotidianos com a possibilidade de atribuir uma dimensão pedagógica ao processo de criação colaborativa com os bailarinos.

A dança aqui se apresenta como procedimento de açáo e crítica a estrutura urbana do Rio de Janeiro, ousando cruzar as divisóes políticas, econômicas e imaginárias (se formos obedecer as categorias analíticas propostas por Henry Lefebvre) sem que este procedimento torne-se discursivo no palco. Lia redefine ordens espaciais, sugere caminhos e traçados para perguntar: aonde podem ir estes corpos urbanos? Quais as implicações políticas na organização da cidade destes atravessamentos cotidianos? Diante do seu trabalho, o público é convidado a indagar-se como a política espacial restringe a circulação, e como pode a prática artística atuar sobre essas reservas. Mais do que tudo, a coreógrafa investiga, a partir desse procedimento, como tais políticas espaciais definem subjetivamente o corpo de um dançarino.

O que chamo aqui de procedimento coreográfico é uma estratégia de composição a partir de movimentos gerados nas instâncias do quotidiano, ou seja, em um vocabulário de movimento que difere da semântica espetacular ou virtuosistica da dança. A ousadia em atravessar as barreiras simbólicas que dividem a cidade do Rio de Janeiro faz com que os dançarinos, todos os dias, ao adentrarem a favela, reiterem o convite para que o encontro com o outro, com o desconhecido que permanece latente no espaço urbano, se renove. Ali, na resposta intuitiva gerada em cada travessia cotidiana, causada pelo estranhamento constante, é que se articula a dimensão política do trabalho da Companhia. No palco, e incisivamente sobre os corpos em cena, essa dimensão se apresenta em força de presença, em uma corporealidade que extrapola a temática dos espetáculos que compóe.

A presença teimosa nesse bairro é um gesto contra a opacidade criada pelo tratamento excludente da configuração urbana atual, em uma coreografia incessante que repete nos encontros diários a pergunta: como este estar ali muda este corpo que dança? 
Para manter o espaço de ensaio na Maré, e concretizar o trabalho de estabelecer o que chama de Escola de Danças, os bailarinos performam uma série de gestos que contém em si uma força transformativa e que nos revela que o princípio das composições residem nas micropolíticas ${ }^{2}$ no cotidiano em Alagados.

A Favela da Maré é um lugar de exclusão de muitos. São 130 mil habitantes a quem falta transporte efetivo e o planejamento urbano de infraestruturas básicas. A Maré é formada por dezesseis subdivisóes, pequenas municipalidades que marcam também as subdivisóes do crime organizado, cartéis que comandam o trafego de drogas. Nesse lugar, a ONG Redes de Desenvolvimento da Maré funciona como uma iniciativa da comunidade, iniciada com o intuito de preparar jovens para a entrada no hermético sistema de ensino superior brasileiro. Logo a organizaçáo passou a abarcar iniciativas na área de cultura e arte educaçáo, oferecendo modos alternativos para fomentar o engajamento político da comunidade.

A ideia de uma atuação política que parte de uma articulação da habilidade em produzir meios simbólicos é a semente do procedimento coreográfico de Rodrigues. O que se discute em seu gesto de ocupação é o conceito de exclusão em si, apontando sua imanência à concepção urbana do Rio. A exclusão permanece como um processo de abstinência de circulação territorial (visível na fragmentação urbana), mas tem uma dimensão simbólica mais grave, que atinge ideais de participação política, visto que determina a desarticulação e isolamento dos microterritórios urbanos. "A favela vai para além dos territórios que ocupa", escreve a historiadora da arquitetura Paola Berenstajn Jacques (2001, p. 106). Em seu livro, Arquitetura da Ginga, Jacques investiga a noção de ocupação como um processo que ocorre em três níveis distintos: o primeiro o de um preenchimento de espaços abandonados no perímetro urbano (de circulaçáo bem como a ocupação material de abrigos), o segundo sendo os modos de como esses assentamentos se movem ao longo do processo de formalizaçáo da cidade, e, finalmente, desenhando deslocamentos dos moradores sobre o tecido urbano.

Rodrigues, a partir de sua presença na Maré, permite um movimento onde os dançarinos e os demais habitantes de Alagados são postos em uma mesma zona de contato e ali são convidados a compartilhar estratégias de corporealidade cotidianas, implicando uma cocriação de vocabulários, que tornar-se-âo a semântica do 
movimento da coreógrafa. O espetáculo da dança, que nasce desses encontros efêmeros, compóe-se a partir da sucessão de momentos e conjunçóes corporais que ocorrem na Maré.

As peças elaboradas no palco erguido em seu teatro-escola têm uma dramaturgia própria, notadamente com a utilização de poucos recursos cênicos. A força dramática produzida mantém-se nos corpos de contato, condensada na expressividade de movimento do corpo. A precariedade intensifica ainda mais a presença singular de cada um dos corpos em cena e enfatiza a força e extensão do corpo relacional da companhia.

As portas abertas. O público, uma mistura de qualquer coisa pública, qualquer coisa heterogênea formada por corpos de circulação, é um corpo único que aguarda o início da cena em frente ao teatro. Alguém inicia um assobio e senta-se no chão. O espetáculo começa. No intervalo, Lia senta-se em uma cadeira de plástico em meio aos espectadores. Com a plateia composta por curiosos, especialistas ou ativistas, conversa, permanecendo mais próxima de um grupo de jovens, alunos de dança da Redes da Maré. Ouço suas inquietaçóes, sua curiosidade estendida a partir da ação cênica que acabaram de partilhar. Há de se ter imensa generosidade para aceitar uma dança que nos leva a um estado de não entender. Há de entregar-se com coragem para sentar-se ali, no meio dessa heterogeneidade de compreensóes entregues a um espetáculo cheio de sentidos, composto de uma narrativa que não se autoexplica.

Caso alguém indagasse sobre o que é essa dança, a resposta mais apropriada seria devolvida na forma do questionamento de Spinoza que ainda ecoa: o que pode o corpo? Mas a pergunta que fazem os jovens à coreógrafa é: o que significa o corpo naquela cena? A indagação é fruto de um sentimento de desconforto, ofendidos e definitivamente desconfiados pela nudez presente na tal cena. $\mathrm{O}$ que poucos percebem é que encenação da Cia. de Danças extrapola o teatro da Maré, a Avenida Brasil, e integra imperceptivelmente a cacofonia da cidade do Rio de Janeiro, em uma dança que explora o corpo como matéria, sendo concebida náo a partir de uma acumulação de significados apenas, mas como um jogo de estados de permanência e de fluxo. E esse jogo é o que o espetáculo e sua estratégia coreográfica desnuda.

Rodrigues não se incomoda por náo poder fornecer respostas, e resiste, em sua delicada provocação de encontros possíveis. Assim, 
sua companhia torna-se, na Maré, uma ação estética que nega a reprodução de uma visão funcionalista da ação social da arte, ainda atribuída às práticas artísticas contemporâneas.

Suas coreografias iniciam-se antes do contato com o palco, posto que são o conjunto de atividades de engajamento espacial sugeridas em seu trabalho. Além do cruzamento de zonas opacas que acontece a partir da entrada na Maré nos ensaios diários, reverte-se a partir do calendário da Escola de Danças da Maré o fluxo tradicionalmente desenhado na Zona Sul do Rio, já que, quando em cartaz, os espetáculos são a condição permissiva para que o público da dança entre também nesse território desconhecido de Alagados, território esse que permanece, até o momento da dança de Rodrigues, inacessível, invisível e impenetrável. Aqui o discurso cênico afirma que a favela é o lugar da dança, e que o lugar da dança deve ser o das diferenças corporais, encontradas no contraste com o outro e no contraste produzido por hábitos relocalizados em outros sítios. Ao negar-se a construir uma representação pasteurizada e encenada do que percebe como formas de uma corporealidade periférica, Rodrigues nos convida a uma articulação diferente de nosso próprio corpo no espaço da cidade.

Assistir as performances da Lia Rodrigues Cia. de Danças da mesma forma como se postaria em qualquer outro teatro é impossível, porque o corpo do espectador é compreendido de uma forma tangencial a uma generalizaçáo do que constitui uma plateia da dança contemporânea. Ao entrar na Maré, o visitante/espectador é confrontado com novas "interconexôes e alinhamentos" da cidade, e não há outra forma de adentrar o universo criativo de Rodrigues senão a partir da diferenciação de sua própria experiência urbana (Manning, 2009, p. 15). Esse realinhamento não se dá em forma de subjetivaçóes de sentidos, mas a partir da corporealidade e atravessamentos da experiência da plateia. O público é testemunha da exclusão, ao ter de ir ao teatro utilizando o sistema de Vans que saem da Zona Sul em direção a Maré. A experiência coreográfica inicia-se quando a pontualidade exigida na chegada, para que o público se encontre diante da Van, antecipa o momento onde corpos estranhos vão estar juntos em estado de congregação diante do palco. Atravessam a cidade juntos, nos automóveis coreografados pela Companhia, para levar a todos em segurança da Zona Sul até Maré. A coreografia prossegue, no atravessamento dos limites de uma segurança simbólica e espacial, 
até que o público adentre o território de Alagados. Iniciada no convite para compor uma nova massa-público da dança, essa dança excede a composição cênica por transbordar a experiência estética ficcional, passando a ser a invençáo da própria cidade em suas reversóes de fluxos urbanos tangíveis justificados e tornados possíveis a partir da experiência estética (Rancière, 2006, p. 76). Complementam o discurso e a composição expostos no palco, estes procedimentos que se estabeleceram no cruzamento das vizinhanças até então intocáveis, intransponíveis. A coreografia é repartida entre moradores, dançarinos e público, nesse desenho de trajetórias e encontros, justificados pela dança de Rodrigues.

Após dez anos de permanência teimosa na Maré, estes procedimentos de atravessamento estão mais sedimentados e já são caminhos possíveis contra a violência implícita nas políticas de restrição espacial característica da estrutura urbana do Rio de Janeiro. Permanecer na Maré, ao invés de assimilar a lógica de um visitante, tornou-se a estratégia principal para desfazer a dicotomia de poderes que marca as políticas urbanas daquela cidade. Assim, essa é, acima de tudo, uma prática relacional - uma coreografia relacional e, em última instância, como define Bourriaud, um processo que se apoia na orquestração de encontros que redefine a micropolítica de convivialidade (Borriaud, 2002, p. 9). Contrária a uma lógica simplista sobre as trocas sociais oriundas da produção estética, Rodrigues propõe fricções como base de um processo de diálogo genuíno (Mouffe, 2005, p. 40).

Em meu projeto investigativo, aproximei-me dos dançarinos após a turnê que celebrou o vigésimo aniversário da Companhia, e no efeito da criação de um novo espetáculo. Sugeri que assistisse e delineasse, tal qual sombra, as trajetórias dos dançarinos de casa ao trabalho. A proposição era simples: encontrar o dançarino em sua casa, de manhã cedo, e acompanhá-lo até a Maré. No caminho, conversaríamos sobre a paisagem, as impressóes sobre as transformaçóes urbanas pelas quais passa o Rio atualmente, em face aos jogos olímpicos e a Copa do mundo de Futebol, que se aproximam. Eventualmente, pretendia investigar as singularidades de entendimento do conceito de presença por cada integrante que acompanhasse.

$\mathrm{O}$ procedimento foi executado com três dançarinos, nenhum dos quais vivia na Maré. O que me interessava era documentar a relaçáo destes com o momento de atravessamento do espaço doméstico até a favela, contorno e abrigo de seu local de trabalho. 
Lia frequentemente conduz seus ensaios com os olhos fechados, revelando um modo peculiar de dirigir a presença dos corpos em cena. Desconfio que esse contato diretivo conecte sua direção de cena com a intensidade das relaçóes de movimento no palco, ao invés de partir das formas corporais. Nos ensaios de Pororoca, que ocorriam durante minha visita, eram testados pontos de aterrissagem e chegada, formaçóes e intençóes de contato.

O gesto de direção de olhos fechados sugere a compreensão da coreógrafa em relação a sintonizações de presença (Manning, 2009), que são em si um ato de resistência política. Presença define-se por aquilo que extrapola a forma do corpo, mas que atribui qualidades às formas que se produz em movimento (Nancy, 1994). Em Rodrigues, o conceito de presença apresenta-se como uma qualidade dinâmica de permanência, estabelecida na habilidade de mover padróes de circulação pré-estabelecidos.

O procedimento com cada um dos dançarinos iniciava-se no portáo de suas casas, e dali partíamos juntos, atravessando suas rotas cotidianas. Apesar da conversa, evitei que nosso encontro fosse entendido como uma entrevista e frequentemente estávamos em silêncio, caminhando lado a lado, compartilhando a percepção sobre os ruídos dos carros e ônibus, ou apenas compartilhando sentindo na paisagem móvel.

Eventualmente, eu os provocava a discutir noção de presença, conceito táo contestado no campo da performance. Frequentemente a noção de presença é evocada como indicativo de níveis de percepção no palco, definição que dificilmente serve quando se trata de eventos que ocorrem na cacofonia urbana. No palco, e, a partir de uma centralização na percepção da cena sob o ponto de vista do performer, tal atentividade pode ser sugerida como um ideal de execuçáo física, mas no espaço da cidade, na dispersão de atenção e no deslocamento da preensão da presença pelo performer ou pelo público, essa definição é incompleta. É um equívoco presumir que possa ser alcançada uma consciência mais sofisticada, que considere as peculiaridades efêmeras do que constitui o lugar urbano, o local, como se no espaço da cidade houvesse uma possibilidade de apreensão completa pelo sujeito que percebe o espaço. Essa presunçáo, contida no conceito de presença supracitado, nos levaria a esquecer das qualidades efêmeras que se atualizam na ocasião da presença, e que estas qualidades espaço-temporais náo precedem o evento/performance do encontro 
entre sujeito e lugar. Estão, portanto, disponíveis a serem percebidas somente, e tão somente a partir da atualização que as relações entre corpos presentes concretizam. Enquanto a noção de atentividade total persistir na compreensão do conceito de presença, força-se um retorno à dicotomia entre ator e local (perceber o que está presente e o que se apresenta separadamente do aparato perceptivo), a ideia de que o ambiente preexiste o evento sentido ignora a importância da ação na atribuição de sentido e na presentificação de um estado de lugar.

No trabalho de Lia, o conceito de presença emerge entre corpo e lugar, a partir da ideia de fluxos de permanência. Corpo e lugar são entidades que integram em sincronia o evento presente, onde presença se define no movimento/evento do encontro entre agente e lugar. Esse evento informa condiçóes espaciais que configuram um outro registro ao encontro que não é do âmbito da significação. Presença é entendida como a dispersão de atençóes entre sujeito e lugar, apresentada no momento do encontro. É um evento de absorção e dispersão do presente.

Nas obras dos filósofos Jean Luc Nancy e de H. U. Gumbrecht encontra-se a defesa de um conceito de presença como o registro que completa o âmbito da significação, diferenciando-se da consciência (saber/conceitual). É crucial a compreensão desta divergência entre saber sobre e aquilo o que se apresenta atravessando as ferramentas passíveis de compreensão de significado semânticos. A difusão do conceito de presença, tal como apresentado por eles, é crucial, particularmente na teoria da dança, que ainda privilegia a interpretação de significados contidos no corpo em cena, ultrapassando a análise da prática do movimento que se constitui a partir de corpos conceituais.

Jean Luc Nancy defende a ideia de que presença produz mais do que sentido, crucial para compreender uma pedagogia de movimento urbana contida na prática do movimento em si e que náo depende da articulaçáo da dramaturgia em cena. Nancy descreve a presença relacionando-a estritamente com a ideia de decisão, ou "[...] uma projeção que apresenta e determina o que é possível em um dado momento" (Nancy, 1994, p. 85). Ele rejeita a noção de uma apreensão do que se apresenta, ou seja, corpos ou objetos que se asseguram numa essência, desvelada na atentividade do encontro com o sujeito. Para Nancy, presença é o que se atualiza dentro das tendências de movimento possíveis, afastando da ideia de captura de uma essência e defendendo o conceito como a movimentação de uma contingência 
de encontro. Ao partir da definição de Nancy, evita-se a análise do corpo performativo exclusivamente sob o âmbito da significação, permitindo a transcendência de uma noçáo substancialista do corpo em cena, e a inevitável reificação da forma decorrente dessa lógica analítica. Para Nancy, presença emerge quando há a impossibilidade de permanência, na agitação e na ação de situar-se. Gumbrecht, complementarmente, chama este momento de 'apagar'. O effacement é, para esse autor, a associação da presença com a habilidade rítmica de executação de um movimento que causa mudança no estado de corpo (Gumbrecht, 2004, p. 58). Fazer-se presente, assim, é o processo que se caracteriza por estar em movimento com (Nancy, 1994, p. 170).

Presença, no trabalho de Lia, é a força que estabelece a organização de potenciais entre o que já tomou forma (aqui o corpo e as configuraçóes urbanas) e a possibilidade de tornar-se extensivo junto ao ambiente, seguindo o conceito de extensivo contínuo, tal qual proposto por Alfred North Whitehead, situar-se. Náo se trata de enfatizar características do lugar, ou seja, torná-las presentes ao aparato perceptual a partir de um estado de atençáo específico do corpo. Também náo é o corpo, a partir de uma contração em cena, que torna-se mais presente. Presença é a habilidade de atravessar e mover o que se apresenta em estado latente ou determinado, em outras palavras, é um estado de mover sentidos latentes. A coreógrafa requer que os dançarinos cruzem a cidade e entrem num espaço invisível ao poder público e ao discurso constitutivo da cidade, e de exclusão, alterando assim rituais cotidianos que configuram os corpos de seus dançarinos e, por consequência, as informaçôes disponíveis ao seu projeto criativo. Trabalhar com a presença, estar presente, nesse sentido, é a disponibilidade em transformar-se em outro corpo, aprender (e preender) modos de navegaçáo em ambientes não cênicos.

Os encontros, que passam a ser possíveis a partir dos procedimentos coreográficos de Lia, produzem efeitos de presença que miram o espaço urbano a partir das potencialidades contidas nos contatos de risco (Tonkiss, 2005, p. 71). Tais contatos geram contiguidades de presença, que constituiriam, no vocabulário de Nancy, uma "topografia de distinçôes" (Nancy, 1994, p. 181). Assegurar a circulação entre espaços de diferença, de encontro com o diferente - o que Tonkiss define como contato de risco (não por oferecer um risco de violência direta, mas sim por expor distinções dos modos de percepção e ocupação do espaço) - é o modo pelo qual Lia estabelece essas topografias de dis- 
tinçóes. Esse conceito determina a compreensão do âmbito político no trabalho de Rodrigues na Maré, visível nas cartografias de convergência das diferenças que compóem suas danças.

Encontrei C. no segundo dia de procedimentos na Escola de Danças. Em transição entre os apartamentos nossa conversa foi pautada por histórias sobre a atual crise imobiliária no Rio, originada no descontrole e escalada do preço dos aluguéis. Ao transitar na Maré com C., o território que se abria diante de nossos passos era claro e senti-me em absoluta segurança. Tão à vontade que os meninos de oito anos, que vendiam cocaína sobre uma improvisada mesa de plástico na boca da ruela, tornaram-se invisíveis pra mim. Eu os vi, mas sua presença não foi assustadora; a ação ilícita e a crueldade do evento foram dissipadas na nossa caminhada. C. me pediu que parasse de bater fotos, náo porque poderia ter o equipamento roubado, mas porque estava potencialmente expondo uma camada visível da violência e ilegalidade que compóem aquele território, transgredindo assim os acordos silenciosos que permitiam à companhia coabitar aquele espaço. Após quatro anos, C. havia aprendido a estar atento e em alerta, navegando em perfeito conforto com aquele espaço e nos lastros de imensa gentileza e generosidade que fazem possível a convivência com a violência urbana. Com ele, o sentido do lugar se construiu para mim em suavidade e hospitalidade.

No dia seguinte, eu acompanhava N., que integrava não havia muito tempo a companhia. O sentido de perigo tomou todo o contorno do trajeto, impregnou a rua do teatro. $\mathrm{O}$ medo dela, ainda estrangeira naquele território, ritmava meu caminhar. Sentia medo, porque ela sentia medo, e juntas seguíamos em suspensão receosa. Ela ainda emanava, na qualidade condensada dos seus passos, um incidente que ocorrera havia uma semana: os dançarinos tiveram que abandonar o ensaio quando duas facçóes do tráfico de drogas haviam iniciado uma disputa a apenas alguns metros do teatro. Perguntei a ela por que havia optado por dançar com Lia Rodrigues e ela respondeu-me com tranquilidade, em tom que facilmente poderia ser confundido com desengajamento político. N. disse que estava ali pelo vocabulário físico da companhia, completando que, para ela, a presença do grupo na Maré era indiferente.

Após alguns dias, em que passei observando os ensaios, coletando a fala e os percursos dos dançarinos, pude perceber um desconforto compartilhado sobre a presença da companhia naquele 
lugar. Para eles, o porquê de estarem em Alagados não era tão óbvio. Predominava a visão de que, sua presença ali, deveria ser acompanhada da execução de algum trabalho social, ou ao menos do ensino direto da dança por meio de workshops na comunidade. Todavia, conforme proponho aqui, é o tecido relacional que constitui o plano compartilhado na dança, que compóe o mais forte lastro social desse trabalho coreográfico.

O lugar e a relação estabelecida com os corpos participantes é o diagrama pedagógico e relacional de Rodrigues. Intangível, a estratégia não é prescritiva nem pretende ensinar códigos de corpo, espaciais ou relacionais, contidos em si. A prática da arte (assim como a da política) se apresenta como força que sugere tendências de movimentos de congregação, em encontros entre aquilo que ainda não se pode imaginar. Deleuze e Guattari desenvolvem o conceito do plano de imanência, conceito este que oferece uma interessante solução a despeito da estratégia de composição de Rodrigues. $\mathrm{O}$ plano de imanência é posto como o campo onde estáo estruturas relacionais que precedem a linguagem; por outro lado, a linguagem se inscreve nesse plano relacional. Eles descrevem que "[...] o plano de imanência não é um conceito que possa ser ensinado, mas sim a imagem do pensamento" (Deleuze; Guattari, 1994, p. 37).

Pode-se confundir o plano de imanência com a linguagem, possivelmente quando não são consideradas as noçôes de presença e de presente imediato. $O$ plano de imanência não é a estrutura, mas o movimento em si. Facilmente pode-se confundir o plano de imanência com a linguagem, decorrente de um desenlace conceitual entre a noção de presença e o que Deleuze chama de presente imediato. $\mathrm{O}$ plano da imanência não é uma estrutura, mas o movimento onde as estruturas se relacionam, movimento de onde elas derivam.

A adoçáo desse conceito, diante do trabalho de Rodrigues, oferece um contraponto à tradição de intervenção comunitária com a qual sua prática se relaciona. As condiçóes do trabalho criam um campo em si, que ocorre antes do plano e do espaço-tempo da composição cênica para o palco. Esse campo permanecerá como uma coreografia que não pertence ao espaço ficcional da dança, mas informa as práticas relacionais da cena, entre os dançarinos, público e comunidade.

$\mathrm{Na}$ noção de extensivo contínuo, proposta por Alfred North Whitehead, encontramos o delineamento de um plano onde se assegura o potencial de divisóes, encompassando simultaneamente as 
entidades físicas e temporais que se relacionam. Conforme descrito por Steve Goodman e Luciana Parisi, o extensivo contínuo "[...] expressa um esquema geral de relaçóes entre entidades e o mundo atualizado" (Goodman; Parisi, 2009).

Whitehead escreve:

Extensão, além da espacialização e temporalização é o esquema geral de relaçôes, que proporciona a capacidade de muitos objetos em serem soldados em apenas uma unidade da experiência. Então, um ato de experiência tem um esquema objetivo de ordem extensiva, pelo fato duplo de que sua própria perspectiva é um dos objetivos tem um conteúdo de extensão e outras entidades atuais são objectificadas a partir da retenção de suas relaçôes extensivas. Estas são relaçóes extensivas mais fundamentais do que as relaçóes especiais temporais ou espaciais (1978, p. 67).

A cidade talvez seja o campo extensivo mais expressivo com o qual podemos nos relacionar. A experiência ali ocorre de forma semelhante ao que descreve Whitehead: precede as distinçóes temporais e espaciais e mantém o potencial de todas as relaçóes atuais. A açáo relacional e a experiência sáo modos distintos tornados uma categoria espaço-temporal. Ao invés de ação no espaço ou uma sensação sobre um espaço pré-existente, tornam-se plano de imanência. No trabalho da Cia. de Danças da Maré, assegura-se que esse plano seja mantido em expansão e que a cidade náo seja reduzida a segregaçóes sociais e estratificações dos encontros possíveis.

Todo movimento deve ser considerado. Todo movimento afeta a habilidade de improvisar nos encontros, compor. Não é um detalhe que os dançarinos passem uma hora, antes do início dos ensaios, higienizando o chão do galpão, ainda em construção. Não é irrelevante que há apenas água fria nos vestiários, nem é irrelevante o movimento abrupto que sucede os sons de tiros em Alagados. Não é irrelevante a amizade com o restaurante local, a proibiçáo velada de câmeras fotográficas, nem os modos em que desdobram-se corporealidades dos bailarinos na Maré, do outro no espaço de um outro outro.

O papel que tem as pequenas e efêmeras intervençóes (de dança, artes visuais ou performance) é o da preservação do senso de inadequação necessário para a complexificação do plano de imanências, provocando aberturas no sentido do lugar e no corpo sentido. Assim, a implicação política da ação estética é a de manter o estado de constante transformação diante das repetiçóes de gestos, práticas e caminhos cotidianos. A implicação política da ação ou provocação 
artística está na habilidade de sustentar uma experiência específica do espaço-tempo inimaginada, mantendo um espaço onde diferenças possam ser sentidas e performadas. A presença de Lia na Maré não é menos efêmera após dez anos de insistência - pois seu trabalho viabiliza a noção de um cotidiano efêmero, passível de gestos que o distendam, que transformem a repetição dos trajetos cotidianos pela elasticidade dos encontros possíveis. A efemeridade da experiência urbana tornase parte das composiçóes cênicas na ressonância de movimentos, que são performados distintivamente, e também no âmbito singular dos trajetos de cada bailarino, antes de sua chegada no teatro-escola.

Ao propor aos dançarinos que, em troca do tempo que estes me cederiam para que eu cruzasse a cidade com eles, lhes preparasse uma janta, pressupunha um corpo (cultural e simbólico) específico aos membros da companhia de danças. A segunda entrevistada era crudista. Despertava às $4 \mathrm{~h} 30$ da manhã para práticas meditativas. Fosse eu seguir o que havia proposto inicialmente, deveria acompanhá-la nesse ritual do alvorecer, cantar e comer mangas. No caminho para Alagados, conversamos sobre sua ausência do Rio por quase quinze anos, e perguntei-lhe se aquela era a mesma cidade que havia deixado, ou se a reconhecia como um outro lugar. Questionei se havia algum momento em particular naquele trajeto onde a paisagem se apresentava de forma mais intensa, atraindo um tempo de sua atenção, já que confessara estar normalmente ausente do lugar, imersa em leituras durante o trajeto. No momento da minha pergunta, passávamos por um viaduto onde o mar se estendia com intensidade, ao longo de quase 180 graus ao redor do que podia abarcar a vista. Ela disse que o momento em que mais prestava atençáo à paisagem era um túnel, uma subtração de contornos que fazia com que a presença da cidade se abstraísse. A paisagem se forma a partir de nossas próprias condiçóes corporais, ela me disse ali, naquele túnel vazio de cidade, cheio da ausência do mar.

O corpo é aprendido como posse, mas não a partir da construção de sentidos relacionais. O que é ter um corpo que dança, o que é ter um corpo que não tem? As identidades de movimento se produzem quando o corpo náo está em estado de dança. Se, como nos sugere Elizabeth Grosz, a arquitetura é o domínio de regulaçóes e manipulaçôes de espaços construídos (Grosz, 2001), práticas como as de Lia afirmam que o corpo é o lugar onde essas regulaçóes podem ser contestadas, exteriorizadas e coreografadas em discursos silenciosos. 


\section{Notas}

${ }^{1}$ Whitehead define sociedade como "[...] um nexo de ordem social que causa a permanência de um objeto ou criatura, ou uma ordem social que causa uma ordem pessoal e particular" (1978, p. 34).

${ }^{2}$ Durante uma das minhas visitas a companhia, em 2010, os dançarinos estavam aborrecidos, pois seus produtos de limpeza do local de ensaio haviam sido furtados. Esse evento ilustra apenas as mais simples cenas do cotidiano que perpassam as aulas técnicas e os ensaios, que compóem o dia a dia da Companhia. Movimento de ocupaçáo e atravessamento da Companhia com a comunidade local.

\section{Referências}

BOURRIAUD, Nicolas. Relational Aesthetics. Dijon: Les Presses du Réel, 2002.

DELEUZE, Gilles; GUATTARI, Félix. What is philosophy? New York: Columbia University Press, 1994.

FOUCAULT, Michel. Of Other Spaces [palestra]. In: MIRZOEFF, Nicholas (Org.). The Visual Culture Reader. London; New York: Routledge, 1980. P. 229-237.

GOODMAN, Steve; PARISI, Luciana. Extensive Continuum. Towards a rhythmic anarchitecture. Inflexions, Montreal, n. 2. Disponível em: <http://www.senselab.ca/inflexions/ volume_4/n2_parisigoodmanhtml.html>. Acesso em: 13 maio 2009.

GROSZ, Elizabeth A. Architecture from the Outside: essays on virtual and real space. Cambridge, Mass.: MIT Press, 2001.

GUMBRECHT, Hans Ulrich. Production of Presence: what meaning cannot convey. Stanford, Calif.: Stanford University Press, 2004.

JACQUES, Paola Berenstein. Estética da Ginga. Arquitetura das favelas através da obra de Hélio Oitica. Rio de Janeiro: Casa da Palavra, 2001.

MANNING, Erin. Relationscapes: movement, art, philosophy. Cambridge, Mass.: MIT Press, 2009.

MOUFFE, Chantal. The Return of the Political. London; New York: Verso, 2005.

NANCY, Jean-Luc. The Birth to Presence. Stanford: Stanford University Press, 1994.

RANCIÈRE, Jacques. The politics of Aesthetics: the distribution of the sensible. London; New York: Continuum, 2006.

TONKISS, Fran. Space, the City and Social Theory: social relations and urban forms. Cambridge, UK; Malden, Mass.: Polity, 2006.

WHITEHEAD, Alfred North. Process and Reality, an Essay in Cosmology. New York: Harper, 1978.

Bianca Scliar Mancini é pesquisadora afiliada do Sense Lab, da Concordia University, em Montreal, onde desenvolve projetos em Arte e Filosofia. Atualmente trabalha no IMMEDIATIONS, uma cooperação Interinstitucional que enlaça arquitetura, dança e processos colaborativos. Coordena o Grupo Moinho, em Florianópolis, oferecendo oficinas de pesquisa e criação e fomentando processos artísticos interdisciplinares. E-mail: bibimove@gmail.com

Recebido em 20 de dezembro de 2012 Aprovado em 02 de abril de 2013 